\title{
自然の河川の姿に範をとった非決定的なデザイン手法による河川空間整備
}

\section{A study on the river space design by the non-concluded design method}

referred to the natural $r$ iver forms.

\section{伊藤 登* 天野光一 $* *$ \\ By Noboru Itoh Koichi Amano}

\section{1.はじめに}

身のまわりの環境に対する国民の意識は、かつて ないほどの高まりをみせ、河川においても昭和 50 年 代の環境護岸（緑化護岸やほたる護岸）、昭和60年 代の親水護岸を経て、多自然あるいは近自然型の川 づくりが現在盛んに進められている。しかし、これ らには水際の自然にのみ着目してその復元に重点を 置くものも多く、また河川景観整備では、不自然な 線形の護岸や樹木が 1 本もない利用しにくい空間な ど、形の必然性や利用上の快適性に乏しい例も多い。

いずれも河川景観を形づくる自然の河川の姿とし ての地形や植生の特徴、人々が利用する空間に求め られる条件等についての分析やデザイン的検討が不 十分であること、また予め形を全部決定しょうとす ること等、自然的なものや利用等を考台合せたデザ イン手法が明確となっていないためと考えられる。

現在の河川整備に求められる設計手法のひとつは、 人間の存在と利用を前提として、その場所の河道特 性に応じた自然的な河川景観を形成し得る河川空間 のデザイン手法である。本稿は、このようなデザイ ン手法の構筑を目指し、地形や植生等から構成され る自然の河川の姿に範をとり、設計から施工に至る 過程で順次デザインを行う非決定的なデザイン手法 による河川空間設計の方法論を、具体の設計・施工 例を通して提案することを目的とする。

\section{2. 河川の姿の普遍性と個別性}

河川の水辺は、急流は急流ならではの、河口部は 河口部ならではの表情や環境（普遍性）を有し、ま たそれぞれの河川に固有の歴史・文化的な特性(個 別性)を有している。

筆者が考える普遍性ある河川景観とは、自然の河
川そのままの景観（そのままの自然は決して利用し やすいものではない)ではなく、利用上の快適性を 有すると同時に、河川だからこそ持ち得る多様な魅 力に富む景観である。そのような河川景観を具現化 するためには、自然の河川の風景を構成する主たる 要素である地形・植生の詳細な観察から河川景観を 特徴づける形やその組み合わせを選びだし、それら を洗練・モデル化したものを場所に応じて形を整え ながら配置するというデザイン手法、すなわち、我 が国の多くの河川で適用可能な河川景観の普遍性に 依拠するデザイン手法が必要である。一方、河川景 観の個別性は、河川自体の表情よりも沿川都市等の 歴史性等による方が大きく、一般解は得にくい。

河川工学の分野では、表 1 に示すように同一の河 床勾配を有する河道区間の場合、ほぼ同じ大きさの 河床材料となり、低水路幅や深さ等の地形的特徵も 概ね共通するといわれている。また、類似した特徵 を持つ区間をセグメントと呼んでいる。山本 ${ }^{1)}$ は、 生態系を工学的観点から河道特性として把握するこ とを目的として、河川区域内の植生の生育環境を区 分している。その中で、河川空間内の植生は、河床 材料や表層土壤、洪水時の流速等の植生の生育環境 がほぼ同様となるセグメントによって河川縦断方向 の分布が、また水際、河岸斜面部、河岸肩部等の位 置によって横断方向の分布が概ね定まるとしている。 これは同一セグメントの場合、自然の河川の姿を構 成する地形と植生は類似していることを示している。

セグメントは河川景観のすべてを決定づけるもの ではないが、それに対応した地形的特徴、植生立地 の特徴は、縦断方向で見た場合に河川景観のある程 度の基調を表象するものとして、他の河川での適用 可能性を示しているといえる。 


\section{3、自然の河川の姿に範をとった河川デザイン手法}

筆者が提案する自然の河川の姿に範をとった河川 空間のデザイン手法は、河川景観の全体像を定める 際に用いる景観のモデル（以下に示す河川景観タイ プ）の適用とこれを実際につくり上げていく際に用 いる地形や空間の個々の要素（以下に示すデザイン パーツ）の活用の両者から構成される。実際には、 この両者を設計対象となる河川の状況や利用等のあ り方を分析して、適宜組み合わせてデザインを行う こととなる。

\section{(1) 河川景観タイプ}

セグメントは、縦断方向で見た場合に河川景観の ある程度の基調を表象するものといえるが、実際に は同一セグメントでも河道内の様々な条件や工作物 の設置等によって河川景観は異なるものとなる。ま た、セグメントと実体としての河川景観との関わり について分析した例は、これまであまり多くはない。

筆者は、建設省木曾川下流工事事務所の委託調査 2)を遂行する中で、木曾三川下流部（木曾川、長良 川、揖斐川）について現地踏查を実施し、河川の全 体像を把握することを目的として河川景観の類型化 を行う機会を得た。全体景として同一の基調を有す るかという観点から類型化を行い、類型毎の地形の 平面的特徵と横断的特徵、植生立地の特徴を端的に 表現する河川景観設計の観点から河道内の河川景観 の全体像を定めるためのモデルの構築を行った。

その結果、干潟景観タイプ、河原景観タイプ、中 洲景観タイプ、ワンドタイプの 4 つの基本的なタイ プを得た。これらのタイプとセグメントの関係をみ ると、表 1 に示すセグメント2-2、セグメント3にあ たり、セグメント2-2では河原景観タイプ、中洲景 観タイプ、ワンドタイプ、セグメント3では、干潟 景観タイプ、河原景観タイプ、中洲景観タイプがモ デルとして適用可能である。

ここで得たタイプは、河川の基本的な姿・形とし ての地形と植生についての骨格的な特徴をおさえて いるがゆえに、自然の作用がつくりだした形の典 型・プロトタイプとして、河川の空間づくりの範と なり得るものであるが、その適用にあたってはセグ メントを参考としながらも整備対象となる区間の状 況をよくみきわめることが必要である。これらの夕
イプのうちの 1 つである河原景観タイプ（他の大河 川において一般にみられ、河川のデザイン上汎用性 が高いと考えられる）の空間の構成と地形・植生の 基本的扱いを図 1 に示す。

表 1 各セグメントとその特徵 1

\begin{tabular}{|c|c|c|c|c|c|}
\hline & \multirow{2}{*}{ セグメントM } & \multirow{2}{*}{ セグメント 1} & \multicolumn{2}{|c|}{ セダメント2 } & \multirow{2}{*}{ ヒグメント 3} \\
\hline & & & $2-1$ & $2-2$ & \\
\hline 地 形 区 分 & \multicolumn{5}{|c|}{ 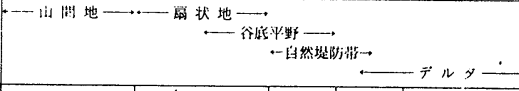 } \\
\hline $\begin{array}{l}\text { 河來材料の } \\
\text { 代表的径 } d_{k}\end{array}$ & さまざま & $\dot{2} \mathrm{~cm}$ 以上. & $\begin{array}{c}3 \mathrm{~cm} \sim \\
1 \mathrm{~cm}\end{array}$ & $\begin{array}{l}1 \mathrm{~cm} \sim \\
0.3 \mathrm{~mm}\end{array}$ & $0.3 \mathrm{~mm}$ 以下 \\
\hline 河岸構成物留 & $\begin{array}{l}\text { 河林河掉に炭が出 } \\
\text { ていることか多 } \\
\text { い. }\end{array}$ & 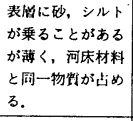 & $\begin{array}{l}\text { 下譄は河 } \\
\text { 同一, 細 } \\
\text { 卜,粘土。 }\end{array}$ & $\begin{array}{l}\text { 岀材料と } \\
\text { 砂, シル } \\
\text { D混合物. }\end{array}$ & シルト・粘土 \\
\hline 勾配の目安 & さまざま & $1 / 60 \sim 1 / 400$ & $1 / 400 \sim$ & $1 / 5000$ & $1 / 5000 \sim$ 水平 \\
\hline 驼 行 程 度 & さまざま & 曲りが少ない & \begin{tabular}{|l|} 
蛇行が潄 \\
川楅水溧上 \\
い所では \\
または島 \\
\end{tabular} & $\begin{array}{l}\text { Lいが, } \\
\text { 比が大き } \\
8 \text { 字蛇行 } \\
\text { の発生 } \\
\end{array}$ & $\begin{array}{l}\text { 蛇行が大さいもの } \\
\text { もあるが小さいも } \\
\text { のもあっ. }\end{array}$ \\
\hline 河岸侵食程度 & 非常に潡しい & 非常に潡しい & $\begin{array}{l}\text { 中, 河床才 } \\
\text { きいほう } \\
\text { よく動く. }\end{array}$ & $\begin{array}{l}\text { 材料が大 } \\
\text { が本路は } \\
.\end{array}$ & $\begin{array}{l}\text { 弱, ほとんど水路 } \\
\text { の位地は動かな } \\
\text { い. } \\
\end{array}$ \\
\hline 低水路の平均溧さ & さまざま & $0.5 \sim 3 \mathrm{~m}$ & $2 \sim 8$ & $8 \mathrm{~m}$ & $3 \sim 8 \mathrm{~m}$ \\
\hline
\end{tabular}

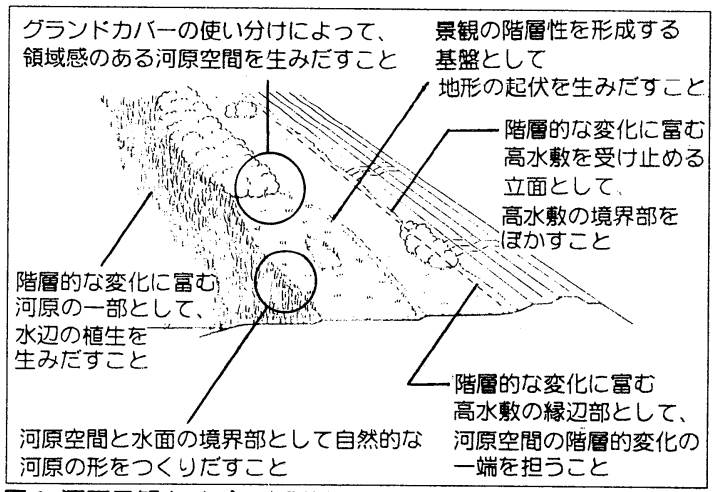

図 1 河原景観タイブの空間構成とその地形・植生の基本的扱い ${ }^{2}$

(2) デザインパーツ

河川景観タイプは、あくまでも河川景観の全体像 を示すものであり、実際の設計においてはこまかな 地形の形や空間の形についての詳細な知見が必要と なる。これが筆者がデザインパーツと呼ぶ設計上必 要不可欠な要素である。

筆者は昭和61年度土木計画学研究発表会において、 河川の流れがつくりだす自然の水辺の形に着目し、 河岸と寄洲の形態的特徵について分析し、それを洗 練化することで護岸等のデザインに応用可能である ことを示した ${ }^{3)}$ 。また、翌62年には、同研究発表会 において、河川空間における活動の特徴とその活動 を引き起こす要因の分析を行った ${ }^{4)}$ 。そして、河川 活動空間の特性を明らかにし、活動空間の配置方法 と空間の基本的な型を示した。また、各活動空間を 分節・接合する「移行带」（図4 中にその一部を示 
す）とでも呼べる要素の存在を発見し、微高地や段 差等の形態によるものと乾湿や河床材料の変化等の テクスチュアによるものがあることを明らかにした。

\section{4. 非決定的なデザイン手法}

自然の河川は、構造物のようなはっきりとした形 をもっているものではない。水辺は水の辺りであり、 本来的には境界が曖昧な領域である。摇れ動くその 曖昧さを一度にすべて決定づけることは、設計上か なり無理がある。自然の姿・形に範をとるならば、 むしろある程度の圥長性を設計に取り入れることの 方が理にかなっているといえよう。これを先に示し た自然の河川の姿に範をとった河川空間のデザイン 手法でみると、河川空間デザインの方法として、ま ず「河川景観の全体像を設定し、それに基づいてデ ザインパーツを配置し」、その上で「形を見極めな がらデザインパーツのすり合せを行う」という、日 本庭園の布石にみられるようなあらかじめす心゙てを 決定するのではなく、条件がそろったところで決め ていくという非決定型のデザイン方法が成立可能と いえる。これは、目標とする河川の姿の大要を見極 め、その後順次要所となる部分から決定していくと いうデザインプロセスである。構造物設計とは異な り、形がはっきりとしないものを設計するのだから こそ、水の流れがつくるような細かな地形のアン ジュレーションや樹木の見立てや配置等は、施工中 のデザイン監理の段階まで決定を遅らせる方が身体 感覚的に優れた河川空間形成が可能となると考えら れる。

\section{5. 自然の河川の姿に範をとった非決定的なデザ イン手法の適用}

本研究では、筆者の一人が実際にデザインを行う 機会を得た建設省福島工事事務所の整備事業である 阿武隈川（福島市）の例を通じて、このような考え 方に基づく河川空間デザインの方法論の適用を試み る。

\section{(1) 河川景観の全体像の設定 (整備方針の設定)}

設計対象である渡利地区は、福島市の顔のひとつ である福島県庁付近の右岸側の延長 $1.3 \mathrm{~km} 、 川$ 幅約 200mの区間である。対岸の隈畔地区は、歴史性と都
市性の両面を併せ持つ良好な水辺空間であるのに対 し、背後に住宅地が広がる渡利地区は、周辺に自然 に形成された河原が広がってはいたが、大部分は河 岸にヤナギが自生し、平均水位よりも2-3m高い造成 盤上にヨシやオオブタクサ等の高茎草本が生い茂る 利用も困難な荒れた印象の場所であった。

河川景観の全体像のモデルには、先に示した河川 景観のモデルのひとつである河原景観タイプを用い ることとした。これは、施工区間付近の自然の河原 の状況が水際から緩やかな起伏をともなって堤防へ と至っていること、水際にヤナギの分布がみられる ことなど、河原景観タイプの特徵をよく残している

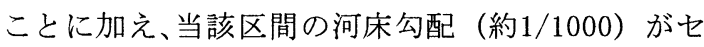
グメント的にも河原景観タイプが成立し得ると考え られるからである。

\section{(2) デザインパーツの配置・組合(施工前の設計)}

この全体像をもとに、既にデザインパーツとして の知見を得ている河岸・寄洲の自然の水辺の形や活 動空間の特性を活用し、空間としての組み立てを行 う。河川微地形の設計対象物への適用性とデザイン パーツとして利用する主な空間の型は、先の研究成 果を応用し、図 $2^{3)}$ 及び図 $3^{4)}$ に示すとおりとした。

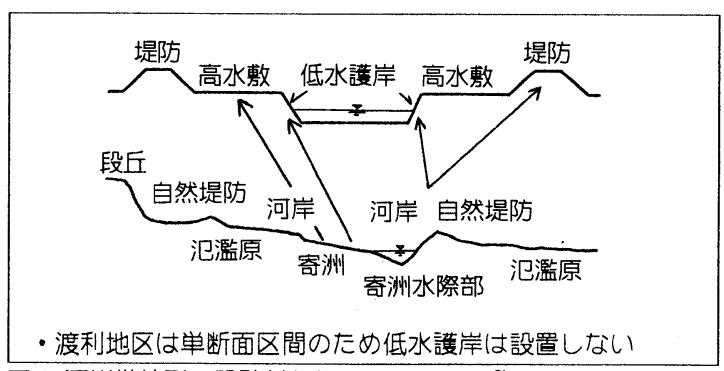

図2 河川微地形の設計対象物への適用関係 ${ }^{3)}$

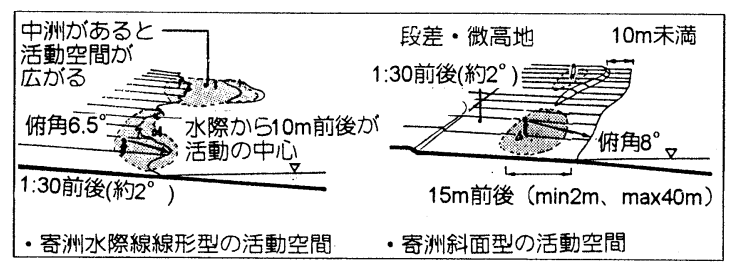

図3 適用した主な空間の型 ${ }^{4)}$

\section{(1)概略的な盤高の設定}

河川の場合、通常高水敷や堤防天端の計画盤高が 定められており、そのため従来の河川整備では一様 平坦な高水敷が形成されがちであった。自然の河川 
にこのような一様な地盤は存在しない。自然の河川 の姿に範をとったデザインの特徵のひとつは、水際 や高水敷の利用や自然の扱いを先の全体像をもとに 設定し、当該河川の水位記録等をもとに、それぞれ 最適な盤高を求め、水際から高水敷を経て堤防に至 る地形のレベル変化を創出することにある。

渡利地区では、（1）で示した全体像を基に、図 2、 図 3 の知見を応用して、対象区間の平均水面標高 $57.4 \mathrm{~m}$ 、年最大流量時の平均水面標高約 $60 \mathrm{~m}$ 、堤防天 端標高65mの関係を考慮し、まず空間全体として図 4 に示す活動と対応した低中高の平坦ではない $3 つ$ の基本盤を概略的に設定した。

低位盤は、平均水位に近い標高58m前後の盤、中 位盤は確率的に年に 1 度は水が上がる標高 $60 \mathrm{~m}$ 前後 の盤、高位盤は年に 1 度の確率では水が上がらない 標高 $61.5 \mathrm{~m}$ 前後の盤である。低位盤は、図 3 に示す ように水際線から $10 \mathrm{~m}$ 程度の範囲に人々の親水活動 に利用される礫主体の寄洲的な空間とヨシの新たな 生育空間、中位盤は水際線から $20 \mathrm{~m} \sim 30 \mathrm{~m}$ 程度の範 囲にピクニックや野草つみ等の活動や親水活動を眺 める空間、高位盤は安全に散策を楽しめる空間を想 定した。このうち、低位盤は、基本的には維持管理 を行わない空間であり、中高位盤は人々の利用に合 せて、現在住民主体で草刚り等の維持管理を行って いる空間である。

(2)移行帯を活用した盤の配置

次は、これら 3 種の盤高の空間を移行帯の概念

(前述した活動空間を分節・接合する要素。図 4 参 照）を活用して配置する段階である。盤高の異なる 空間の配置を決定することによって、目標とする河 川の全体像の概略を定めると同時に、粗造成工事に 必要な情報を得る。

盤の配置は、水際や盤面の縦断的な出入りを定め る移行帯、地表の材料や植生等の水際々の比高や距 離を表象する横断的な移行带、丘や段差等の空間相 互を面的に関係づける移行帯を活用して行なった。 図 4 は、盤面の配置を模式的に示したものである。

河川空間整備における通常の設計は、すべてを決 定するが、ここでは基本的な盤高とその空間配置の みを決定している。これは目標とする河川空間の姿 を皆で共有し、第 1 段階の施工（粗造成）を行う上 で必要十分な決定である。地形や樹木の表情が大切
な設計であるからこそ、より細かな決定はこの段階 で決定する必要は必ずしもない。

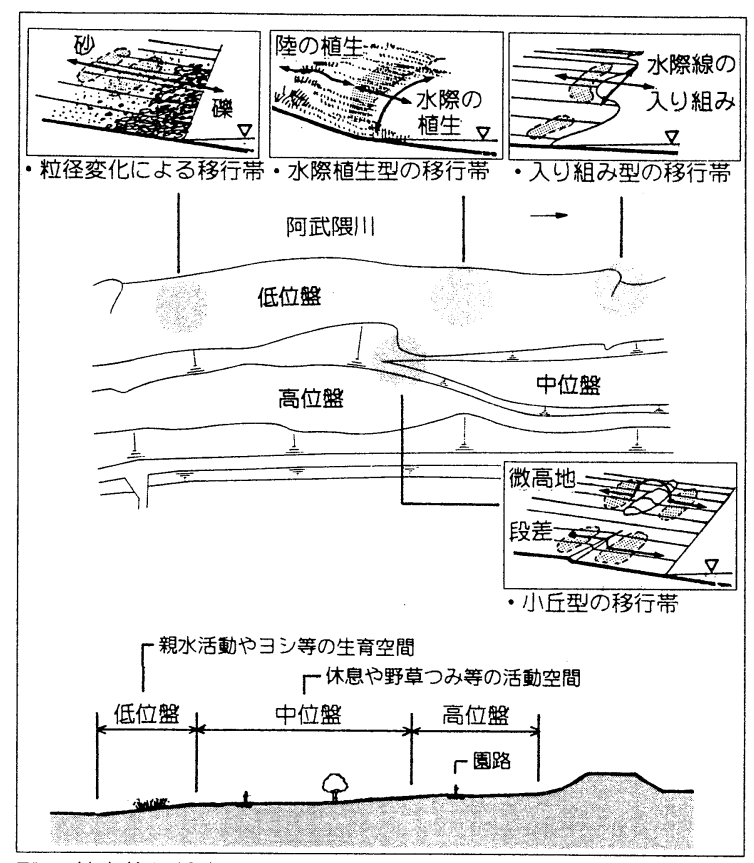

困4 基本的な盤高とその空間配置

(3) デザインパーツのすり合わせ (施エ中の設計)

自然の河川の姿に範をとる河川空間のデザインの 特徵のひとつは施工時におけるデザインパーツのす り合わせである。ここでは、隣合う空間の境界部の 調整、既存樹木のデザイン的扱い、見試しの3つに ついて述べる。

(1)隣合う空間の境界部の調整

都市の中心部など、人々によく利用される場所で は、上記の通常のデザインに加え、隣合う空間の境 界部の調整がデザイン上大きな意味を持つ。これは 分節と接合によって認識される空間の身体的な感覚 が利用者にとって特に重要となるからである。境界 部のディテールデザインの基本は、空間の落ち着き と変化を感じられるようにすることである。これは 空間と空間の関係性のデザインであり、空間相互の 融和的関係を生み出すことをその目的とする。

渡利地区の場合、先に配置した移行帯のディテー ルと、空間と空間との境界部に現れる視覚的な稜線 の扱いが空間を分節・接合する上で重要であること が整備を通じて明らかとなった。

具体的には、高さの異なる盤によって区分される 2 つの空間をその法肩を漸次的に低くし、全体に緩 
やかな勾配を有するひとつの斜面とする方法が、2 つの空間を違和感なくひとつの空間に統合し、空間 相互の融和的関係を生み出す上で効果があった。ま た、図 5 に示すように視覚的稜線による「ここの空 間」と「あそこの空間」という 2 つの空間としての 認識と、「連続したひとつの空間」としての認識の 両義性が空間相互の融和的関係を生み出す上で効果 的であった。

これらの空間境界部のディテールデザインは、全 体の地形のアンジュレーションの文脈の中で如何に 美しく見えるかを考慮し、空間の身体感覚としての 居心地の良さを現場で実際に確認しながら、施工前 には予め決めがたい、微妙ではあるが空間全体への 影響の大きい数 $10 \mathrm{~cm}$ 程度の地形の操作を施工者に指 示したものである。施工時において、形の洗練化を 図る対応を行うからこそ、居心地の良い空間形成が 保証できるといえる。

このようにすることで、写真 1 に示すようにはじ めて自然の河川のように水位の変動に応じて水際線 の形が変化して見える水辺空間が得られる。これは 通常の河川整備においては得られない景観的効果で ある。

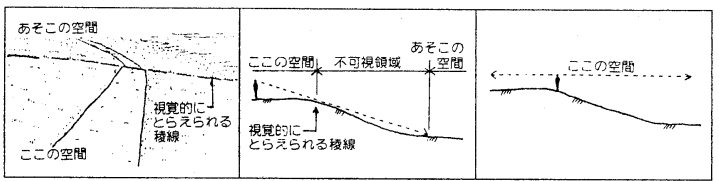

図5 視賞的な稜線

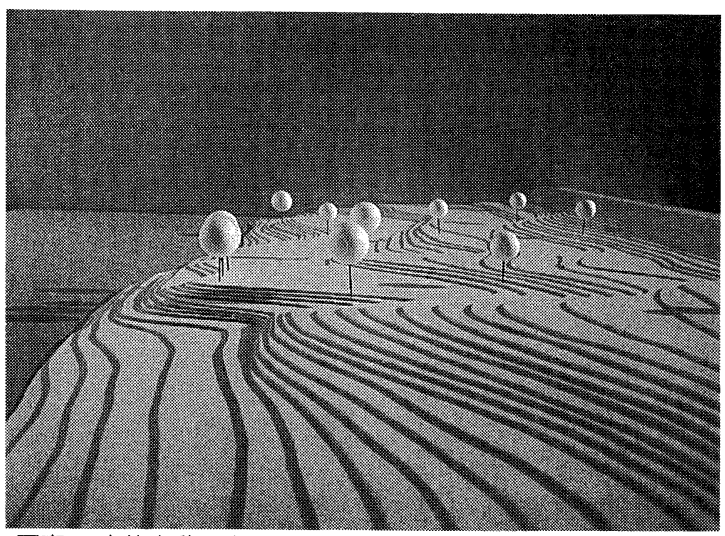

写真 1 水位变動に忍じた水際線の变化（模型）

(2)既存樹木のデザイン的取り扱い

樹木は、空間を分節・接合し、空間の印象を高め る要素としてその姿・形がきわめて重要である。し
かし、渡利地区もそうであるように既存樹木には株 立ち状のものも多く、一本の樹木として株分けが可 能であるか、またその際にどのような姿・形の樹木 となるかなど、施工時にはじめて分ることが多い。 写真 2 と写真 3 は、水際に存在する樹木を現場で見 立てて、水際に樹木を残しながら、適宜高水敷上に 移植した状況を示している。これらは、主要な視点 場からの眺め、活動空間における身体的な居心地の 良さ、園路上のシークエンス、そして地形の起伏と のバランスを考慮して現場でデザイン、移植したも のである。また、移植においては、既存樹木との枝 振りのバランスを整えるため、数本の樹木をまとめ て植えて株立状の移植しない既存樹木の姿との脈絡 を持たせている。

今回の整備を通じて、既存樹木については施工の 進捗にあわせて、適宜その株分けと樹木の見立てを 行い移植することがデザイン上有効であることが 分った。これによって、空間構成要素としての樹木 にはじめて姿・形の良さを与えることができ、樹木 を中心とした空間に融和的な関係を持たせ得る。

(3)見試し(みためし)

見試しは、河川工事に際し、流れの作用によって 周囲に起こる洗掘や堆積等の状況を踏まえて、必要 に応じて構造物の形や配置を見直すというかつての 河川整備の考え方のひとつである。渡利地区におい ても小洪水時に既存樹木周辺での局所的な流れの作 用による部分的な形の変化がみられ、見試しの大切 さを改めて確認することができた。このような形の 変化は、水理学的にも予測困難であるため、見試し によって適切に修正を図ることは、その場所ならで はの水辺空間を形成する上で重要な方法である。ま た河川の形に範を置き、水の影響を加味したデザイ ンであるからこそ、大切な行為である。

渡利地区においては、河岸の既存樹木の根元から 約 $1 \mathrm{~m}$ 程度水位が上がった小洪水時に、樹木周辺で の流れの状況や草の倒伏の状況を確認し、樹木周辺 で流れがスムーズとなるようにやや窪んでいた樹木 背後の地形を盤高で約 $50 \mathrm{~cm}$ 程高めたことと、樹木根 元部の河原石による補強の合計 2 回の見試しを実施 した。この後は、洪水時に大きな地形の変化がなく、 安定した状態を保っている。 


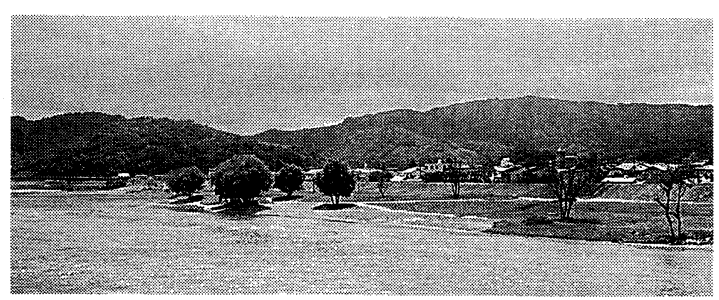

写真 2 保全樹木が水辺を引き立てている渡利地区の全詈

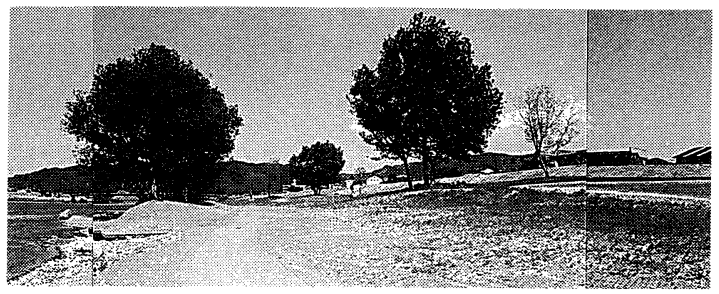

写真3 緩やかな起伏と樹木配置とのバランスがとれた 渡利地区における水辺空間のデザイン

\section{6. 自然の河川の姿に範をとった非決定的デザインの 方法論的特徵}

自然の河川の姿に範をとる非決定的河川デザイン の最たる特徵は、施丁の段階にまでデザ・ンン行為が 及ぶことであり、その効用は次の 3 点にある。

(1)単なる多自然型河川工法とは異なり、河川空間全体 として自然的な印象の空間づくりが可能なこと。

(2)あらかじめ決められない事項や施工時に発生する不 測の事項に対応可能となること。これは近年デザイン 監理として認められつつある行為を既に内包している ことを意味する。

(3)精緻な設計精度が要求されるアンジュレーションの デザインを施工の進渉にあわせて行うことで、身体感 覚的に居心地の良い河川空間形成を保証し、かつ当初 設計の負荷が軽減されること。

\section{7. まとめと今後の課題}

本研究では、河川ならではの多様な魅力を有する 河川空間を実現可能とするデザインの方法論として、 自然の河川の姿に範をとる非決定的な河川空間のデ ザインの方法を示した。また、これまで、設計当初 にすべてを決定する行為がデザインといわれてきた が、形を見極めながら詳細を定める非決定型のデザ インが成立し得ることを例証し、そのデザイン的効 用を示した。

今後の課題として、自然の河川の姿のプロトタイ プの充実、デザインパーツの充実とそのスケール ディメンジョンの統計的把握、実際の整備を通じた デザイン例の充実とデザイン論としての検証の充実 等の諸点がある。なお、一連の研究にあたっては、 東京大学土木工学科篠原修教授に総括的ご指導を 賜った。木曾三川での調査、渡利地区での整備にお いては、建設省木曽川下流工事事務所並びに福島工 事事務所の関係各位にご理解とご協力を頂いた。ま た、御代田和弘君、鈴木紀子さんには論文作成の協 力を頂いた。紙面を借りて謝意を表します。

\section{<参考文献 $>$}

1) 山本晃一、沖積河川学、山海堂、1994

2) 木曾三川下流部河川景観検討業務委託、建設省木曽川下流工事事務所 3) 篠原、伊藤他、河川微地形の形態的特徵とその河川景観設計人 の適用、土木計画学研究発表会論文集、1986

4) 伊藤、長谷川他、河川風景主義からみた河川活動空間と景観設 計手法、土木計画学研究発表会論文集、1987

自然の河川の姿に範をとった非決定的なデザイン手法による河川空間整備

伊藤 登 天野 光一

本研究では、河川ならではの多様な魅力を有する河川空間の実現を可能とするデザインの方法論とし て、自然的な河川の姿に範をとる河川空間のデザインを提示するとともに、このデザインを適用するデ ザイン手法は施工の進渉に合せてデザインを実施する非決定型のデザインであることを示した。また、 これらの方法論を阿武隈川の福島市渡利地区に適用し、そのデザイン的効用を明らかにした。

On this study, we present the river space design method referred to the natural river forms, aiming to realize river original various charms. This method can be called non-concluded design method, and one characteristic of this method is to decide river forms by steps of progress of construction. And through a concrete example, at Watari district of Fukushima city in Abukuma-river, we confirmed a validity of this method. 